Research Article

\title{
The effect of riluzole alone and in combination with sodium valproate on pentylenetetrazole induced seizures in swiss-albino rats
}

\author{
Amol Ramrao Jadhav, Kiran Prabhakar Vakade*, Bana Bihari Nayak, \\ Vijayaprasad M. Sangisetti, Vijaykumar N. Abhavathi
}

\begin{abstract}
Department of Pharmacology, PDVVPF's Medical College, Ahmednagar, Maharashtra, India
\end{abstract}

Received: 11 February 2016 Accepted: 12 March 2016

*Correspondence to:

Dr. Kiran Prabhakar Vakade,

Email: dr.kiran84@gmail.com

Copyright: (C) the author(s), publisher and licensee Medip Academy. This is an openaccess article distributed under the terms of the Creative Commons Attribution NonCommercial License, which permits unrestricted noncommercial use, distribution, and reproduction in any medium, provided the original work is properly cited.

\begin{abstract}
Background: Riluzole- a glutamate antagonist is known to enhance antiepileptic effects of various other antiepileptic drugs. The present study was undertaken to evaluate anticonvulsant effect of riluzole alone and in combination with sodium valproate on pentylenetetrazole (Metrazol) induced seizures in swiss-albino rats.

Methods: Pentylenetetrazole (PTZ) $50 \mathrm{mg} / \mathrm{kg}$ intraperitonially (ip) was used to induce seizure in swiss- albino rats. Anticonvulsant effect of riluzole (at 5 $\mathrm{mg} / \mathrm{kg}$ and $10 \mathrm{mg} / \mathrm{kg}$ ) and sodium valproate (at $75 \mathrm{mg} / \mathrm{kg}, 150 \mathrm{mg} / \mathrm{kg}$ and 300 $\mathrm{mg} / \mathrm{kg}$ ) was studied on PTZ induced seizures in albino rats. Also effect of riluzole $(10 \mathrm{mg} / \mathrm{kg})$ in combination with sodium valproate $(75 \mathrm{mg} / \mathrm{kg}, 150 \mathrm{mg} / \mathrm{kg}$ and $300 \mathrm{mg} / \mathrm{kg}$ ) was studied. Parameters such as time of onset of first clonic convulsion in seconds, frequency of clonic convulsion in 60 minute and total duration of entire convulsion in minutes were studied. For statistical analysis unpaired t test was used.

Results: At $5 \mathrm{mg} / \mathrm{kg}$ and $10 \mathrm{mg} / \mathrm{kg}$ doses riluzole per se was not found to produce any significant effect in PTZ induced seizures $(\mathrm{P}>0.05)$. Sodium valproate at $300 \mathrm{mg} / \mathrm{kg}$ dose was found to produce significant antiepileptic effect $(\mathrm{P}<0.001)$ but not at $75 \mathrm{mg} / \mathrm{kg}$ and $150 \mathrm{mg} / \mathrm{kg}$ dose $(\mathrm{P}>0.05)$. Interestingly significant antiepileptic effect was noted with combination of riluzole (at $10 \mathrm{mg} / \mathrm{kg}$ ) with sodium valproate at $150 \mathrm{mg} / \mathrm{kg}$ and $300 \mathrm{mg} / \mathrm{kg}$ dose $(\mathrm{P}<0.001)$.

Conclusions: Riluzole alone was not found to produce any significant protective effect against PTZ induced seizures in albino rats. However riluzole $(10 \mathrm{mg} / \mathrm{kg})$ was found to enhance the antiepileptic activity of sodium valproate.
\end{abstract}

Keywords: Riluzole, PTZ induced seizure, Antiepileptic, Convulsions

\section{INTRODUCTION}

Epilepsy is a chronic neurological disorder characterized by an enduring predisposition to generate epileptic seizures and it has neurobiological, cognitive, psychological and social consequences The definition of epilepsy requires the occurrence of at least one epileptic seizure. ${ }^{1}$ Transient occurrence of signs and or symptoms in epileptic seizure are seen due to abnormal excessive or synchronous neural activity in the brain. ${ }^{2}$ Worldwide, more than 50 million people are suffering from epilepsy. It is more common in young children and elderly people above 65 years. ${ }^{3}$ The overall prevalence rate of epilepsy in India is 5.59 per 1,000 populations. The worldwide prevalence of active epilepsy is between 4 and 10 per 1000 population. $^{4}$
Despite the introduction of several new therapeutic options in the 1990s, a significant fraction of the patients with epilepsy continue to live with uncontrolled seizures. ${ }^{5}$ Although most people with epilepsy become seizure free with appropriate therapy, $30-40 \%$ of patients continue to have seizures despite the use of antiepileptic drugs either alone or in combination. ${ }^{6}$

The potential importance of riluzole a glutamate antagonist in modulating brain electrical activity has been described recently. Riluzole is known to act through a novel modulatory site on the glutamate receptors, which mediate most excitatory neurotransmission in the mammalian brain. This has been shown that riluzole enhances anti-seizure action of known anti-epileptic drugs. ${ }^{7}$ 
Sodium valproate is one of the broad spectrum antiepileptic drug mainly act by potentiating GABA-ergic function and by inhibiting action of excitatory neurotransmitters NMDA/glutamate in the brain. ${ }^{8}$ Sodium valproate is used for different categories of convulsions such as complex partial seizures, simple and complex absence seizures. However it is associating with many side effects like nausea, vomiting, abdominal cramps, diarrhoea, hepatotoxicity and pancreatitis. ${ }^{9}$

There is still a need for an ideal antiepileptic agent with properties like broad spectrum activity, rapid onset of action, least side effects, good oral bioavailability and low cost. ${ }^{10}$ The present study was undertaken to find out the effect of riluzole alone and in combination with sodium valproate on pentylenetetrazole (PTZ) induced seizures in swiss-albino rats.

\section{METHODS}

The study was conducted in the department of pharmacology, PDVVPF'S Medical College and Hospital, Ahmednagar, Maharashtra, India.

The study was conducted only after approval of the institutional animal ethics committee (IAEC).

Animals used in the study were 6-8 weeks old healthy swiss albino rats (150-200 gm) of either sex. ${ }^{11}$

Table 1: Subgroups and intervention done.

\begin{tabular}{|ll|}
\hline Sub group & Interventions \\
\hline Group I & Distilled water (control) \\
\hline Group II & Riluzole $5 \mathrm{mg} / \mathrm{kg}$ \\
\hline Group III & Riluzole $10 \mathrm{mg} / \mathrm{kg}$ \\
\hline Group IV & Sodium valproate $75 \mathrm{mg} / \mathrm{kg}$ \\
\hline Group V & Sodium valproate $150 \mathrm{mg} / \mathrm{kg}$ \\
\hline Group VI & Sodium valproate $300 \mathrm{mg} / \mathrm{kg}$ \\
\hline Group VII & $\begin{array}{l}\text { Riluzole } 10 \mathrm{mg} / \mathrm{kg}+\text { sodium } \\
\text { valproate } 75 \mathrm{mg} / \mathrm{kg}\end{array}$ \\
\hline Group VIII & $\begin{array}{l}\text { Riluzole } 10 \mathrm{mg} / \mathrm{kg}+\text { sodium } \\
\text { valproate } 150 \mathrm{mg} / \mathrm{kg}\end{array}$ \\
\hline Group IX & $\begin{array}{l}\text { Riluzole } 10 \mathrm{mg} / \mathrm{kg}+\text { sodium } \\
\text { Valproate } 300 \mathrm{mg} / \mathrm{kg}\end{array}$ \\
\hline
\end{tabular}

\section{Drugs and chemicals}

- Solutions of PTZ, riluzole and sodium valproate were prepared by dissolving in normal saline. ${ }^{7}$ Every time freshly prepared solutions were used.

- Pentylenetetrazole (PTZ) was used to produce seizures in swiss- albino rats at a dose of $50 \mathrm{mg} / \mathrm{kg}$ itraperitonially. ${ }^{11}$

- Riluzole was administered orally in the dose of $5 \mathrm{mg} / \mathrm{kg}$ and $10 \mathrm{mg} / \mathrm{kg}^{7}$ while sodium valproate was administered orally at $50 \mathrm{mg} / \mathrm{kg}, 150 \mathrm{mg} / \mathrm{kg}$ and 300 $\mathrm{mg} / \mathrm{kg}$ dose. ${ }^{12}$

- Distilled water is used as a vehicle.
Animal Grouping: Swiss albino rats of either sex were divided into nine groups; each group consists of 6 animals.

\section{Inclusion criteria}

One week before the actual day of testing, pentylenetetrazole was injected itraperitonially (i.p.) at a dose of $50 \mathrm{mg} / \mathrm{kg} .{ }^{11}$ Only those rats, which showed clonic convulsions in the next 15 minutes, were selected for the study.

\section{Exclusion criteria}

Animals in which convulsion was not seen after 15 minutes of PTZ administration.

Animals were housed in plastic cages under standard conditions (ambient temperature of $22 \pm 1^{\circ} \mathrm{C}$, natural lightdark cycle, free access to chow pellets and tap water). ${ }^{7}$

\section{Methodology}

- All experiments were done at the same period of the day (between 9.00 a.m. and 12.00 a.m.) to minimize circadian influences on seizure susceptibility. ${ }^{7}$

- After one week of acclimatization, on the day of the experiment, the animals were brought to the experimental laboratory from the animal house. All the animals were checked to rule out any infection, injury or any other illness. The animals were weighed before the beginning of the experiment.

- The animals were injected the control, test drugs, orally under all aseptic precautions, as per the study groups (Table 1). After 30 minutes, PTZ $(50 \mathrm{mg} / \mathrm{kg})$ was administered i.p. under all aseptic precautions. ${ }^{11}$

- Animals were observed for 60 minutes for the occurrence of seizures, and the timing was noted using digital stop clock. ${ }^{3}$ The occurrence of clonic seizure for more than 5 seconds was taken as a positive seizure response and abolition of clonic seizure was considered as protection against PTZ seizures.

\section{Parameters were studied}

- Time of onset of first clonic convulsion in seconds

- Frequency of clonic convulsion

- Total duration of entire convulsion in minutes. ${ }^{3}$

To calculate the frequency of clonic convulsion, all the animals were observed for the period of 60 minutes. At the end of 60 minutes, the animals were inspected for any injury or residual damage.

\section{Statistical analysis}

All quantitative data was presented as mean \pm standard error of mean (SEM). Data was analysed using the 
unpaired student t-test. For all tests, a 'p' value of $<0.05$ was considered as level of significant.

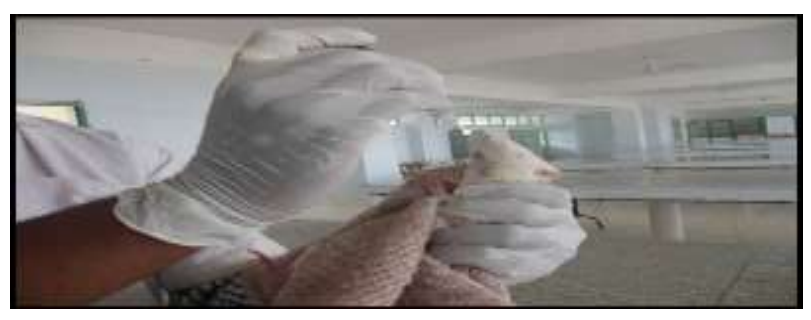

Figure 1: Oral feeding of the drug.

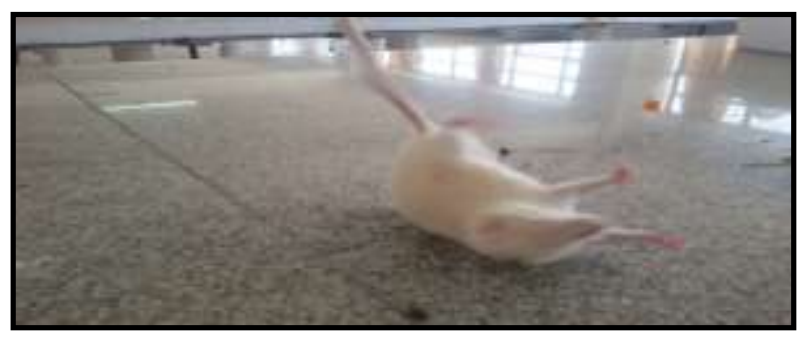

Figure 2: PTZ induced convulsions.

\section{RESULTS}

Table 2 showing results of riluzole on PTZ induced seizures in swiss-albino rats. Riluzole at both doses 5 $\mathrm{mg} / \mathrm{kg}$ and $10 \mathrm{mg} / \mathrm{kg}$ found to produce no significant effect on onset of convulsion in seconds, frequency of convulsion in 60 min duration as well as on total duration convulsions in minute.

Table 3 showing results of sodium valproate on PTZ induced seizures in swiss- albino rats. Sodium valproate was used at three doses $75 \mathrm{mg} / \mathrm{kg}, 150 \mathrm{mg} / \mathrm{kg}$ and 300 $\mathrm{mg} / \mathrm{kg}$. Sodium valproate was found to produce no significant effect at doses $75 \mathrm{mg} / \mathrm{kg}$ and $150 \mathrm{mg} / \mathrm{kg}$ $(\mathrm{P}>0.05)$ on onset of convulsions in seconds, frequency of convulsions in $60 \mathrm{~min}$ duration as well as on total duration of convulsions in minutes. However sodium valproate at $300 \mathrm{mg} / \mathrm{kg}$ dose was found to produce significant effect $(\mathrm{P}<0.001)$.

Table 4 shows the effect of riluzole in combination with different doses of sodium valproate. Riluzole $(10 \mathrm{mg} / \mathrm{kg})$ with sodium valproate $(75 \mathrm{mg} / \mathrm{kg}$ ) was found to produce no significant effect $(\mathrm{P}>0.05)$ on onset of convulsions in seconds, frequency of convulsion in $60 \mathrm{~min}$ duration as well as on total duration convulsion in minutes. However combination of riluzole $(10 \mathrm{mg} / \mathrm{kg})$ with sodium valproate at $150 \mathrm{mg} / \mathrm{kg}$ and $300 \mathrm{mg} / \mathrm{kg}$ doses was found to produce significant effect on onset of convulsion in seconds, frequency of convulsions in $60 \mathrm{~min}$ as well as on total duration convulsion in minutes $(\mathrm{P}<0.001)$.

Table 2: Effect of riluzole on pentylenetetrazole (PTZ) induced convulsions.

\begin{tabular}{|llll|} 
& $\begin{array}{l}\text { Onset of convulsion } \\
\text { in seconds (Mean } \pm \text { SEM) }\end{array}$ & $\begin{array}{l}\text { Frequency } \\
\text { (Mean } \pm \text { SEM) }\end{array}$ & $\begin{array}{l}\text { Total duration in minutes } \\
\text { (Mean } \pm \text { SEM) }\end{array}$ \\
\hline Control & $101 \pm 2.86$ & $24.7 \pm 1.5$ & $41.5 \pm 1.2$ \\
\hline Riluzole $5 \mathrm{mg} / \mathrm{kg}$ & $102.8 \pm 2.8$ & $22.7 \pm 0.8$ & $42.2 \pm 1.8$ \\
\hline Riluzole $10 \mathrm{mg} / \mathrm{kg}$ & $109.5 \pm 2.7$ & $21.7 \pm 0.9$ & $39 \pm 1.00$ \\
\hline
\end{tabular}

Table 3: Effect of sodium valproate on PTZ induced convulsions.

\begin{tabular}{|llll|}
\multicolumn{2}{|c|}{$\begin{array}{c}\text { Onset } \\
(\text { Mean } \pm \text { SEM) }\end{array}$} & Frequency $($ Mean \pm SEM) & $\begin{array}{l}\text { Total duration in } \\
\text { minutes }(\text { Mean } \pm \text { SEM) }\end{array}$ \\
\hline Control & $101 \pm 2.8$ & $24.7 \pm 1.5$ & $41.5 \pm 1.2$ \\
\hline Sodium valproate of $75 \mathrm{mg} / \mathrm{kg}$ & $102.7 \pm 2.1$ & $21.5 \pm 0.6$ & $42 \pm 1.4$ \\
\hline Sodium valproate of $150 \mathrm{mg} / \mathrm{kg}$ & $110 \pm 2.9$ & $21.0 \pm 0.9$ & $37.7 \pm 1.7$ \\
\hline Sodium valproate $300 \mathrm{mg} / \mathrm{kg}$ & $540.7 \pm 17.7^{* * *}$ & $2.5 \pm 0.4^{* * * *}$ & $3.0 \pm 0.8^{* * *}$ \\
\hline
\end{tabular}

$* \mathrm{p}<0.05, * * \mathrm{p}<0.01$, and $* * * \mathrm{p}<0.001$

Table 4: Effect of combination of riluzole $(10 \mathrm{mg} / \mathrm{kg})$ with sodium valproate $(75 \mathrm{mg} / \mathrm{kg}, 150 \mathrm{mg} / \mathrm{kg} \mathrm{and} 300 \mathrm{mg} / \mathrm{kg})$.

\begin{tabular}{|llll|}
\hline Control & $\begin{array}{c}\text { Onset of convulsion in S } \\
\text { seconds (Mean } \pm \text { SEM) }\end{array}$ & $\begin{array}{l}\text { Frequency } \\
\text { (Mean } \pm \text { SEM) }\end{array}$ & $\begin{array}{l}\text { Total duration in } \\
\text { minutes }(\text { Mean } \pm \text { SEM) }\end{array}$ \\
\hline Riluzole $10 \mathrm{mg} / \mathrm{kg}+$ sodium valproate of $75 \mathrm{mg} / \mathrm{kg}$ & $101 \pm 2.86$ & $24.7 \pm 1.5$ & $41.5 \pm 1.2$ \\
\hline Riluzole $10 \mathrm{mg} / \mathrm{kg}+$ sodium valproate of $150 \mathrm{mg} / \mathrm{kg}$ & $541.2 \pm 10.4^{* * *}$ & $21 \pm 0.9$ & $39.8 \pm 1.28$ \\
\hline Riluzole $10 \mathrm{mg} / \mathrm{kg}+$ Sod. Valproate of $300 \mathrm{mg} / \mathrm{kg}$ & $587.3 \pm 3.7^{* * *}$ & $2.8 \pm 0.5^{* * *}$ & $4.2 \pm 0.6^{* * *}$ \\
\hline
\end{tabular}

$* \mathrm{p}<0.05, * * \mathrm{p}<0.01$, and $* * * \mathrm{p}<0.001$ 
Table 5: Effect of sodium valproate at $300 \mathrm{mg} / \mathrm{kg}$ and combination of riluzole $10 \mathrm{mg} / \mathrm{kg}$ with sodium valproate at $150 \mathrm{mg} / \mathrm{kg}$ on PTZ induced seizures in swiss-albino rats.

\begin{tabular}{|lcll|}
\hline Sodium valproate of $300 \mathrm{mg} / \mathrm{kg}$ & $\begin{array}{c}\text { Onset of convulsion in } \\
\text { seconds (Mean } \pm \text { SEM) }\end{array}$ & $\begin{array}{l}\text { Frequency } \\
\text { (Mean } \pm \text { SEM) }\end{array}$ & $\begin{array}{l}\text { Total duration in } \\
\text { minutes (Mean } \pm \text { SEM) }\end{array}$ \\
\hline Riluzole $10 \mathrm{mg} / \mathrm{kg}$ +sodium valproate of $150 \mathrm{mg} / \mathrm{kg}$ & $540.6 \pm 17.7$ & $2.5 \pm 0.4$ & $3 \pm 0.82$ \\
\hline
\end{tabular}

When the effect of sodium valproate at $300 \mathrm{mg} / \mathrm{kg}$ was compared with the effect of combination of riluzole (10 $\mathrm{mg} / \mathrm{kg}$ ) with sodium valproate $150 \mathrm{mg} / \mathrm{kg}$, no significant difference was noted $(\mathrm{P}>0.05)$ (Table 5).

\section{DISCUSSION}

Riluzole is a neuroprotective drug having anti-convulsant, anxiolytic and sedative properties. ${ }^{13}$ In our study we found that riluzole alone at $5 \mathrm{mg} / \mathrm{kg}$ and $10 \mathrm{mg} / \mathrm{kg}$ doses remain ineffective against PTZ induced seizures in swissalbino rats. Also sodium valproate was found to produce no significant effect at $75 \mathrm{mg} / \mathrm{kg}$ and $150 \mathrm{mg} / \mathrm{kg}$ doses. However sodium valproate was found effective at 300 $\mathrm{mg} / \mathrm{kg}$ dose. We also noted that combination of riluzole $(10 \mathrm{mg} / \mathrm{kg})$ with sodium valproate at $150 \mathrm{mg} / \mathrm{kg}$ and 300 $\mathrm{mg} / \mathrm{kg}$ found to produce significant effect against PTZ induced seizure. We also found that sodium valproate at $150 \mathrm{mg} / \mathrm{kg}$ dose found to produce no significant effect against PTZ induced seizure. However sodium valproate at $150 \mathrm{mg} / \mathrm{kg}$ dose when combined with riluzole $10 \mathrm{mg} / \mathrm{kg}$ dose found to produce significant effect against PTZ induced seizures. This shows that riluzole enhances the effect of sodium valproate. ${ }^{7}$

Since according to many experimental trials riluzole is not affecting plasma concentrations of antiepileptic drugs, this positive interaction of riluzole with sodium valproate does not seem to be pharmacokinetic type. ${ }^{7}$

Enhancing effect of riluzole may be due to its inhibitory action on excitatory neurotransmitters because in electrophysiological studies, riluzole prevented both NMDA and veratridine induced excitotoxicity in rat hippocampal slices. ${ }^{14}$ Also in many experimental studies, riluzole was found to attenuate convulsions evoked by both glutamate and kainate in mice. ${ }^{15}$ Moreover, the inhibitory effect on neurotransmission mediated by both the glycine/NMDA and AMPA/kainate receptor complex could be the reason foe efficacy of riluzole in genetic model of seizure prone $\mathrm{DBA} / 2$ mice. ${ }^{16}$ Riluzole may behave as a competitive or as a noncompetitive antagonist at NMDA receptor complex. ${ }^{13,17}$

Observations of many studies related with NMDA receptor antagonists have shown that these drugs enhance the anticonvulsant effect of many conventional antiepileptic drugs, allowing for their significant dose reduction. $^{18}$
So, riluzole could be used as add on drug along with sodium valproate in the management of absence seizure in case of sodium valproate is ineffective as monotherapy. Also we may reduce the dose of sodium valproate by using riluzole as an adjuvant, hence can minimise adverse effects of sodium valproate.

The limitations of the study were; it is an experimental study so it is difficult to extrapolate results of animal study directly on human. So to confirm above results in humans, more clinical studies of riluzole in epileptic patients will be required.

\section{CONCLUSION}

Riluzole alone found ineffective against PTZ induced seizures, however it was found to enhance the antiepileptic effect of sodium valproate against PTZ induced seizures.

\section{ACKNOWLEDGEMENTS}

I am very thankful to Dr. B. B. Nayak Professor department of pharmacology PDVVPF's Medical College, Ahmednagar, Maharashtra, India for his invaluable support in the completion of this study

Funding: No funding sources

Conflict of interest: None declared

Ethical approval: The study was approved by the Institutional Ethics Committee (PDVVPF's MCH/IEC/Pharmac/2012/30)

\section{REFERENCES}

1. Fisher RS, Acevedo C, Arzimanoglou A, Bogacz A, Cross JH, Elger CE, et al. A practical clinical definition of epilepsy. ILAE official report. Epilepsia. 2014;55(4):475-82.

2. Fischer RS, Boas WE, Blume W, Elger C, Genton P, Lee $\mathrm{P}$, et al. Epileptic seizures and epilepsy: definitions proposed by the ILAE and the IBE. Epilepsia. 2005;46(4):470-2.

3. Gopi G, Jayasri P, Elumalali A. Antiepileptic effect of Malachra capitatal. On maximal electro shock (MES) and pentylenetetrazole (PTZ) induced seizures. International Journal of Pharmacology and Toxicology. 2012;2(2):104-8. 
4. Bharucha NE. Epidemiology of epilepsy in India. Epilepsia. 2003;44(1):9-11.

5. White HS. Preclinical development of antiepileptic drugs: past, present and future directions. Epilepsia. 2003;44(7):2-8.

6. La Roche SM, Helmers SL. The new antiepileptic drugs. JAMA. 2004;291(5):605.

7. Borowicz KK, Sekowski A, Drelewska E, Czuczwar SJ. Riluzole enhances the anti-seizure action of conventional anti-epileptic drugs against pentetrazole induced convulsions in mice. Pol. J Pharmacol. 2004;56(2):187-93.

8. Loscher W. Basic pharmacology of valproate; a review after 35 years of clinical use for the treatment of epilepsy. CNS Drugs. 2002;16(10):669-94.

9. Beatriz S, Fagundes R. Valproic acid review. REV Neuroscience. 2008;16(2):130-6.

10. Satoskar RS, Bhendarkar SD, Rege NN. Pharmacology and pharmacotherapeutics. $22^{\text {nd }}$ Ed. Mumbai, India: Popular Prakashan; 2011:124-42.

11. Khanna N, Bhalla S, Verma V, Sharma KK. Modulatory effects of nifedipine and nimodipine in experimental convulsions. Indian Journal of Pharmacology. 2000;32:347-52.

12. Malhotra J, Seth SD, Gupta SK, Gupta YK. Adenosinergic mechanisms in anticonvulsant action of diazepam and sodium valproate. Environmental toxicology and pharmacology. 1996;1(4):269-77.

13. Kretschmer BD, Kratzer U, Schmidt WJ. Riluzole, a glutamate release inhibitor, and motor behavior, Naunyn Schmiedebergs. Arch Pharmacol. 1998;358:181-190.

14. Malgouris C, Daniel M, Doble A. Neuroprotective effects of riluzole on N-methyl-D-aspartate- or veratridine- induced neurotoxicity in rat hippocampal slices. Neurosci Lett. 1994;177:95-9.

15. Mizoule J, Meldrum B, Mazadier M, Croucher M, Ollat C, Uzan A, et al. 2-Amino-6-trifluoromethoxy benzothiazole, a possible antagonist of excitatory amino acid neurotransmission. Anticonvulsant properties. Neuro pharmacology. 1985;24:767-73.

16. De Sarro G, Siniscalchi A, Ferreri G, Gallelli L, De Sarro A. NMDA and AMPA/kainate receptors are involved in the anticonvulsant activity of riluzole in DBA2/mice. Eur J Pharmacol. 2000;408:25-34.

17. Parsons CG, Danysz W, Quack G. Glutamate in CNS disorders as a target for drug development: an update. Drugs News Perspect. 1998;11:523-69.

18. Czuczwar SJ, Turski WA, Kleinrok Z. Interaction of calcium channel blockers and excitatory amino acid antagonists with conventional antiepileptic drugs. CNS Drug Rev. 1996;2:452-67.

Cite this article as: Jadhav AR, Vakade KP, Nayak BB, Sangisetti VM, Abhavathi VN. The effect of riluzole alone and in combination with sodium valproate on pentylenetetrazole induced seizures in swiss-albino rats. Int $\mathrm{J}$ Basic Clin Pharmacol 2016;5:728-32. 